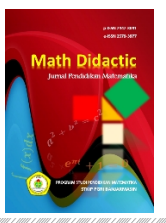

MATH DIDACTIC: JURNAL PENDIDIKAN MATEMATIKA

Volume 4 Nomor 3, September - Desember 2018, halaman 226 - 234

Tersedia Daring padahttp://jurnal.stkipbjm.ac.id/index.php/math

\title{
KEMAMPUAN BERPIKIR KRITIS DAN KOMUNIKASI MATEMATIS SISWA SMP DALAM PEMBELAJARAN PROBLEM POSING BERBASIS KEARIFAN LOKAL KALIMANTAN SELATAN
}

\section{CRITICAL THINKING AND MATHEMATICAL COMMUNICATION ABILITY OF JUNIOR HIGH SCHOOL STUDENTS IN PROBLEM POSING LEARNING BASED ON THE LOCAL WISDOM OF SOUTH KALIMANTAN}

Fahriza Noor, Mayang Gadih Ranti

STKIP PGRI Banjarmasin, STKIP PGRI Banjarmasin

fahriza.noor@ymail.com, mayanggadih@gmail.com

\begin{abstract}
Abstrak: Tujuan dalam penelitian ini adalah untuk mengetahui kemampuan berpikir kritis siswa dan komunikasi matematis siswa dalam pembelajaran problem posing berbasis kearifan lokal Kalimantan Selatan. Metode penelitian ini adalah pretest and posttest control group design. Sampel dalam penelitian ini adalah kelas 7A dan 7B di SMPN 1 Banjarbaru. Pengumpulan data dilakukan dengan menggunakan instrumen tes. Analisis data dilakukan secara statistik inferensial. Hasil penelitian mengindikasikan (1) terdapat pengaruh pembelajaran problem posing berbasis kearifan lokal Kalimantan Selatan terhadap kemampuan berpikir kritis siswa; (2) terdapat pengaruh pembelajaran berbasis kearifan lokal Kalimantan Selatan terhadap kemampuan komunikasi matematis siswa.
\end{abstract}

Kata Kunci: berpikir kritis, komunikasi, problem posing, kearifan lokal

Abstract: The purpose of this study was to determine students 'critical thinking skills and students' mathematical communication in problem posing learning based on South Kalimantan's local wisdom. This research method is pretest and posttest control group design. The sample in this study were $7 \mathrm{~A}$ and $7 \mathrm{~B}$ classes at Banjarbaru 1 Junior High School. Data collection was carried out using test instruments. Data analysis was done by inferential statistics. The results indicate (1) there is effect of problem posing learning based on the local wisdom of South Kalimantan on students' critical thinking skills; (2) there is effect of learning based on South Kalimantan's local wisdom on students' mathematical communication skills.

Keywords: critical thinking, communication, problem posing, local wisdom

Cara Sitasi: Noor, F., \& Ranti, M.G. (2018). Kemampuan berpikir kritis dan komunikasi matematis siswa SMP dalam pembelajaran problem posing berbasis kearifan lokal Kalimantan Selatan. Math Didactic: Jurnal Pendidikan Matematika, 4(3), 226-234. 
Hasil PISA 2015 menunjukkan peringkat Indonesia meningkat dibandingkan tahun-tahun sebelumnya yaitu peringkat ke-62 dari 70 negara yang berpartisifasi (OECD, 2016), tetapi kedudukan Indonesia tersebut masih berada dalam kelompok bawah. Hal ini menunjukkan bahwa kemampuan siswa dalam memecahkan masalah khususnya dalam bidang matematika perlu lebih dikembangkan lagi melalui pembelajaran yang dapat menstimulus kemampuan berpikir tingkat tinggi. Pembelajaran yang melibatkan pemecahan masalah di Indonesia hanya sebesar $20 \%$. Sisanya strategi yang digunakan oleh guru pada saat mengajar di dalam kelas yakni ekspositori, diskusi, kerja praktik dan investigasi (Ragartz dkk, 2010). Oleh karenanya, untuk meningkatkan kualitas mengajar di dalam kelas agar siswa dapat berpikir tingkat tinggi, maka perlu dilaksanakan pembelajaran yang mampu menstimulus hal tersebut, seperti pembelajaran inquiri, investigasi, penemuan terbimbing, matematika realistik, pemecahan masalah, pengajuan masalah, pendekatan saintifik dan lainnya.

Salah satu dari pembelajaran yang disorot dalam artikel ini adalah pembelajaran dengan menggunakan problem posing (pengajuan masalah). Problem posing merupakan pengajaran yang efektif untuk belajar matematika melalui pembangkitan pertanyaan oleh siswa (Mishra \& Iyer, 2015). Ada beberapa cara dalam mengajukan atau mengembangkan suatu masalah yaitu mengidentifikasi dan mengubah kendala dari masalah yang telah diberikan sebelumnya, melihat hal yang biasa menjadi tak biasanya, membuat ambiguitas, dan membuat domain eksplisit (Brown \& Walter, 2013). Silver dan Cai membagi tiga aktivitas yang menjadi patokan dan dapat dipilih dalam pembelajaran dengan menggunakan problem posing yaitu presolution, within-solution, dan post solution (Mahmudi, 2011).

Salah satu aktivitas yang menarik untuk disorot dan diterapkan dalam pembelajaran problem posing yaitu presolution dimana siswa dapat merumuskan soal dari situasi yang diberikan. Situasi disesuaikan dengan perkembangan pembelajaran saat ini yang melibatkan kearifan lokal Kalimantan Selatan sesuai dengan lingkungan siswa, sehingga menghasilkan kebaruan dalam pembelajaran problem posing. Situasi tersebut dapat divisualisasikan melalui gambar yang memuat ciri khas atau budaya Kalimantan Selatan. Ciri khas tersebut berisi objek-objek matematis yang relevan dengan kompetensi yang harus dikuasai oleh siswa, misalnya pasar terapung yang dapat dimanfaatkan untuk pembelajaran aritmatika sosial dan perhitungan aljabar, serta rumah banjar yang dapat dikaitkan dengan bidang geometri. Berdasarkan gambar tersebut, siswa diharapkan dapat membuat persoalan matematika secara kritis, menentukan penyelesaian dan dapat dikomunikasikan secara tertulis.

Dilaksanakannya pembelajaran berbasis kearifan lokal dikarenakan hal tersebut menjadi isu strategis dalam dunia pendidikan di Indonesia pada saat ini yang termuat dalam kurikulum (Permendikbud Nomor 160 Tahun 2014; Kemendikbud, 2012). Tujuannya yaitu untuk membendung budaya-budaya asing yang masuk saat ini dan mengangkat budaya-budaya lokal, khususnya Kalimantan Selatan. Disamping itu, dengan adanya pembelajaran tersebut juga akan membentuk karakter siswa yang lebih mencintai dan memiliki rasa bangga terhadap tanah air Indonesia. 
Berpikir kritis dan komunikasi merupakan dua kompetensi yang harus dikuasai oleh siswa dan merupakan bagian dari berpikir tingkat tinggi (Permendikbud Nomor 160 Tahun 2014; Kemendikbud, 2012). Facione (2013) menyebutkan bahwa terdapat 6 keterampilan dalam berpikir kritis yakni interpretasi, analisis, inferensi, evaluasi, eksplanasi dan regulasi diri. Sedangkan, komunikasi matematis menurut National Council of Teachers Mathematics (NCTM) merupakan cara berbagi ide dan mengklarifikasi pemahaman. Komunikasi matematika meliputi (1) mengatur dan mengkonsolidasikan pemikiran matematis melalui komunikasi; (2) mengkomunikasikan pemikiran matematis secara jelas kepada rekan, guru dan lainnya; (3) menganalisis dan mengevaluasi pemikiran dan strategi matematika; (4) menggunakan bahasa matematika untuk mengekspresikan ide-ide matematika secara tepat (NCTM, 2000).

Berdasarkan paparan tersebut, maka dalam artikel ini akan diuraikan kemampuan berpikir kritis dan komunikasi matematis siswa dalam pembelajaran problem posing berbasis kearifan lokal Kalimantan Selatan.

\section{Metode Penelitian}

Metode yang digunakan dalam penelitian ini adalah kuasi eksperimen pretest and posttest control group design. Penelitian ini dilaksanakan di SMP Negeri 1 Banjarbaru. Sampel dalam penelitian ini adalah kelas 7A sebagai kelas eksperimen dan 7B sebagai kelas kontrol. Teknik yang digunakan untuk mengumpulkan data kemampuan berpikir kritis dan komunikasi matematis siswa dalam penelitian ini yaitu dengan melaksanakan tes awal dan akhir. Analisis data dilakukan dengan mengolah data mentah kemampuan berpikir kritis dan komunikasi matematis siswa menjadi nilai. Data yang sudah diolah menjadi nilai, kemudian diinterpretasikan sebagai berikut.

Tabel 1. Interpretasi Kemampuan Berpikir Kritis dan Komunikasi Matematis Siswa

\begin{tabular}{cc}
\hline $\begin{array}{c}\text { Interval } \\
\text { Nilai }\end{array}$ & Interpretasi \\
\hline $81-100$ & Sangat Baik \\
$61-80$ & Baik \\
$41-60$ & Cukup \\
$21-40$ & Kurang \\
$0-20$ & Sangat Kurang \\
\hline
\end{tabular}

(Sumber: Supinah \& Parmi, 2011)

Nilai dari hasil pengolahan data pretest dan posttest kemudian diuji dengan menggunakan statistik inferensial untuk mengetahui pengaruh pembelajaran problem posing berbasis kearifan lokal Kalimantan Selatan terhadap kemampuan berpikir kritis dan komunikasi matematis siswa SMP yaitu dengan melakukan uji $\mathrm{t}$ independen apabila data berdistribusi normal, sedangkan uji Mann Whitney dilakukan sebagai alternatif apabila data tidak berdistribusi normal.

\section{Hasil Penelitian dan Pembahasan}

\section{Hasil}

Komponen kemampuan berpikir kritis siswa secara operasional diambil dari beberapa indikator yang dinyatakan Facione (2013) yakni interpretasi, analisis, inferensi, dan regulasi diri, sedangkan komunikasi matematis mengadaptasi dari NCTM (2000) yakni konsolidasi dan bahasa. Rata-rata kemampuan berpikir kritis siswa sebelum perlakuan pada kelas eksperimen dan kontrol masing-masing adalah 67,86 dan 72,92 dengan kategori baik. Rata-rata kemampuan berpikir kritis siswa sesudah perlakuan pada kelas 
eksperimen dan kontrol masing-masing adalah 71,43 dan 73,81 dengan kategori baik. Adapun data kemampuan berpikir kritis siswa, sebelum (pretest) dan sesudah (posttest) perlakuan, dapat dilihat pada tabel 2 . baik di kelas eksperimen dan kontrol masingmasing sebesar 1,78 poin dan 7,14 poin. Komponen keempat yakni regulasi diri siswa mengalami peningkatan di kelas eksperimen dan kontrol masing-masing sebesar 10,72 poin

Tabel 2. Sebaran Kemampuan Berpikir Kritis Siswa

\begin{tabular}{ccccc}
\hline Interval Nilai & \multicolumn{2}{c}{ Pretest } & \multicolumn{2}{c}{ Posttest } \\
& Eksperimen & Kontrol & $\begin{array}{c}\text { Eksperime } \\
\text { n }\end{array}$ & Kontrol \\
\hline $81-100$ & 8 & 10 & 9 & 8 \\
$61-80$ & 9 & 16 & 16 & 18 \\
$41-60$ & 6 & 2 & 2 & 1 \\
$21-40$ & 5 & 0 & 1 & 1 \\
$0-20$ & 0 & 0 & 0 & 0 \\
\hline
\end{tabular}

Berdasarkan gambar 1 dan 2, 5,35 poin. Peningkatan tertinggi di kelas diperoleh bahwa komponen tertinggi pada saat eksperimen terletak pada komponen

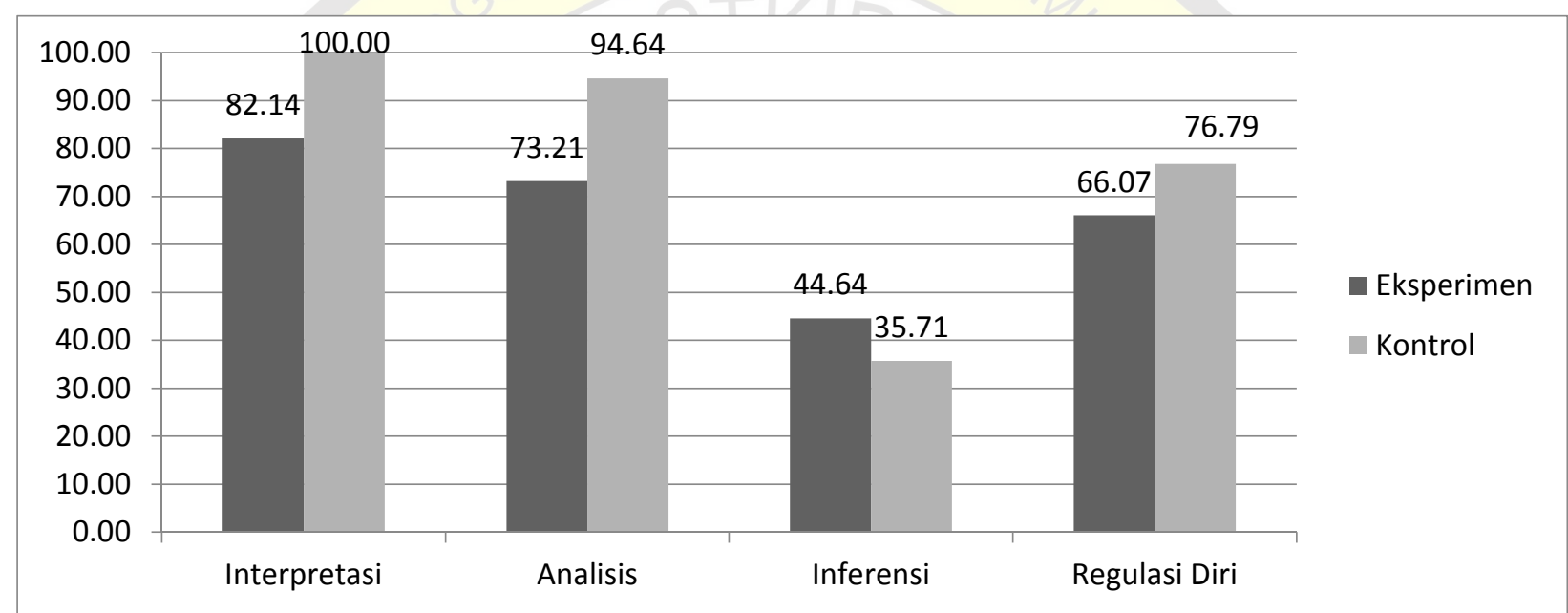

Gambar 1 Komponen Kemampuan Berpikir Kritis Siswa Kelas Eksperimen dan Kontrol Sebelum Perlakuan (Pretest)

pretest dan posttest, baik kelas eksperimen maupun kelas kontrol adalah interpretasi, sedangkan komponen terendahnya adalah inferensi.

Komponen pertama, interpretasi siswa di kelas eksperimen mengalami peningkatan sebesar 12,5 poin, sedangkan di kelas kontrol mengalami penurunan sebesar 1,79 poin. Komponen kedua, analisis siswa mengalami peningkatan di kelas eksperimen sebesar 10,7 poin, sedangkan di kelas kontrol mengalami penurunan sebesar 1,78 poin. Komponen ketiga, inferensi siswa mengalami penurunan interpretasi, sedangkan di kelas kontrol terjadi pada komponen regulasi diri. 


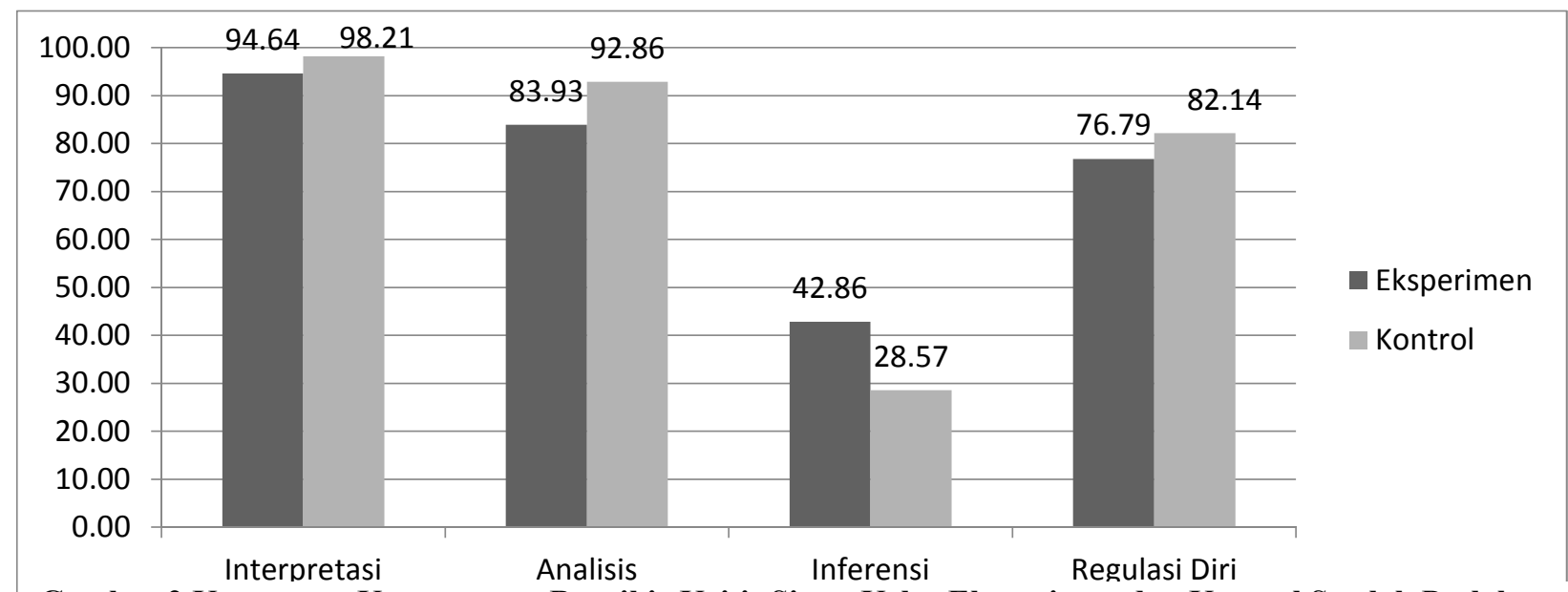

Gambar 2 Komponen Kemampuan Berpikir Kritis Siswa Kelas Eksperimen dan Kontrol Setelah Perlakuan

(Posttest)

Secara keseluruhan, selisih rata-rata kemampuan berpikir kritis siswa sebelum dan sesudah perlakuan di kelas eksperimen dan kontrol masing-masing adalah 8,03 poin dan 1,34 poin. Berdasarkan selisih tersebut, nampak bahwa peningkatan rata-rata kelas eksperimen lebih tinggi dibandingkan kelas kontrol dengan selisih sebesar 9,37 poin.

Analisis data secara statistik inferensial dilakukan dengan menguji normalitas data kemampuan berpikir kritis yang terdapat pada tabel 3. nilai signifikan Liliefors pada kolom Kolmogorov-Smirnov berada di atas taraf signifikansi $1 \%$ atau 0,01 , kecuali untuk data post kritis 7B. Akan tetapi data tersebut berdistribusi normal pada uji Shapiro-Wilk.
Berdasarkan tabel 4, diperoleh nilai signifkansi yang diperoleh adalah 0,099 yang berada di bawah taraf signifikansi 10\%. Hal ini mengindikasikan bahwa terdapat pengaruh pembelajaran problem posing berbasis kearifan lokal Kalimantan Selatan terhadap kemampuan berpikir kritis siswa.

Rata-rata kemampuan komunikasi matematis siswa sebelum perlakuan pada kelas eksperimen dan kontrol masing-masing adalah 66,96 dan 77,68 dengan kategori baik. Sementara itu, rata-rata kemampuan komunikasi matematis siswa sesudah perlakuan di kelas eksperimen dan kontrol masing-masing adalah 78,57 dan 75,00.

Selisih rata-rata kemampuan

Tabel 3. Uji Normalitas Data Kemampuan Berpikir Kritis Siswa

\begin{tabular}{lrrrrrr}
\hline & \multicolumn{3}{c}{ Kolmogorov-Smirnov a } & \multicolumn{3}{c}{ Shapiro-Wilk } \\
\cline { 2 - 8 } & Statistic & \multicolumn{1}{c}{ df } & \multicolumn{1}{c}{ Sig. } & Statistic & df & \multicolumn{1}{c}{ Sig. } \\
\hline Pre_Kritis_7A &, 158 & 28 &, 071 &, 928 & 28 &, 054 \\
Pre_Kritis_7B &, 188 & 28 &, 013 &, 894 & 28 &, 008 \\
Post_Kritis_7A &, 169 & 28 &, 039 &, 893 & 28 &, 008 \\
Post Kritis 7B & .226 & 28 & .001 & .912 & 28 & .022
\end{tabular}

Hal ini mengindikasikan bahwa data kemampuan berpikir kritis siswa, sebelum dan sesudah perlakuan berdistribusi normal, sehingga analisis dilakukan secara parametrik dengan menggunakan uji t independen. komunikasi matematis siswa sebelum dan sesudah perlakuan di kelas eksperimen dan kontrol masing-masing adalah 11,61 poin dan $-2,68$ poin. Berdasarkan selisih tersebut, nampak bahwa selisih rata-rata kelas 
Tabel 4. Uji t Independen

\begin{tabular}{lrrrrr}
\hline & \multicolumn{6}{c}{ t-test for Equality of Means } \\
\cline { 2 - 7 } & $\mathbf{t}$ & df & Sig (2 Tailed) & $\begin{array}{c}\text { Mean } \\
\text { Difference }\end{array}$ & $\begin{array}{c}\text { Std. Error } \\
\text { Difference }\end{array}$ \\
\hline Equal Variance Assumed & 1,678 & 54 &, 099 & 9,37500 & 5,58845 \\
Equal Variance Not & 1,678 & 42,696 &, 101 & 9,37500 & 5,58845
\end{tabular}

Assumed

eksperimen lebih tinggi dibandingkan kelas kontrol yakni sebesar 14,29 poin.

Sebaran komponen komunikasi

19,64 poin di kelas eksperimen, sedangkan di kelas kontrol mengalami penurunan sebesar matematis siswa pada saat pretest dapat dilihat pada gambar 3. Selain itu, sebaran komponen komunikasi matematis siswa pada saat posttest juga dapat dilihat pada gambar 4 .

Berdasarkan gambar 3 dan 4, diperoleh bahwa komponen tertinggi baik pada saat pretest dan posttest adalah konsolidasi. Komponen pertama yakni konsolidasi 5,36 poin. Komponen kedua, bahasa, mengalami peningkatan sebesar 3,57 poin di kelas eksperimen dan stagnan di kelas kontrol.

Secara keseluruhan, selisih rata-rata kemampuan komunikasi matematis siswa sebelum dan sesudah perlakuan di kelas eksperimen dan kontrol masing-masing adalah 11,61 poin dan $-2,68$ poin. Berdasarkan selisih

Tabel 5. Sebaran Kemampuan Komunikasi Matematis Siswa

\begin{tabular}{cccccc}
\hline \multirow{2}{*}{ Interval Nilai } & \multicolumn{2}{c}{ Pretest } & \multicolumn{3}{c}{ Posttest } \\
& Eksperimen & Kontrol & $\begin{array}{c}\text { Eksperime } \\
\text { n }\end{array}$ & Kontrol \\
\hline $81-100$ & 3 & 3 & 7 & 3 \\
$61-80$ & 13 & 25 & 18 & 22 \\
$41-60$ & 12 & 0 & 3 & 3 \\
$21-40$ & 0 & 0 & 0 & 0 \\
$0-20$ & 0 & 0 & 0 & 0 \\
\hline
\end{tabular}

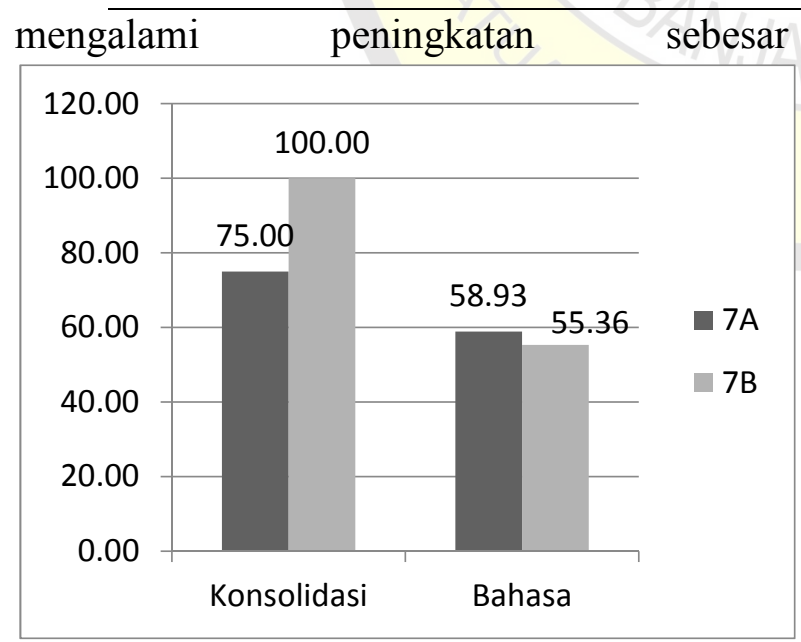

tersebut, nampak bahwa selisih rata-rata kelas eksperimen lebih tinggi dibandingkan kelas kontrol yakni sebesar 14,29 poin.

Analisis data secara inferensial untuk komunikasi matematis siswa dilakukan sama halnya seperti kemampuan berpikir kritis siswa. Uji normalitas data dilakukan terlebih dahulu untuk melangkah ke tahap uji berikutnya. Adapun hasil uji normalitas data komunikasi matematis siswa dapat dilihat pada tabel 6 .

Gambar 3 Kemampuan Komunikasi Matematis Siswa Kelas Eksperimen dan Kontrol Sebelum Perlakuan (Pretest) 


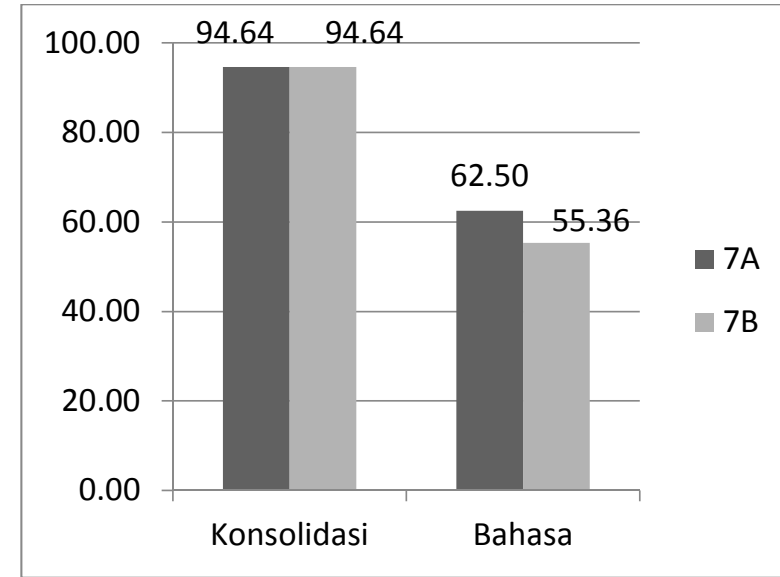

Gambar 4 Kemampuan Komunikasi Matematis Siswa Kelas Eksperimen dan Kontrol Sesudah Perlakuan (Posttest)
Kalimantan Selatan terhadap kemampuan komunikasi matematis siswa.

\section{Pembahasan}

Terdapatnya pengaruh pembelajaran problem posing berbasis kearifan lokal Kalimantan Selatan terhadap kemampuan berpikir kritis dan komunikasi matematis siswa menunjukkan bahwa pembelajaran tersebut sangat relevan untuk pembelajaran matematika dan kebutuhan siswa dalam mengaplikasikan pengetahuan-pengetahuan

Tabel 6. Uji Normalitas Data Kemampuan Komunikasi Matematis Siswa

\begin{tabular}{lrrrrrrr}
\hline & \multicolumn{3}{c}{ Kolmogorov-Smirnov $^{\mathbf{a}}$} & \multicolumn{3}{c}{ Shapiro-Wilk } \\
\cline { 2 - 8 } & Statistic & \multicolumn{1}{c}{ df } & \multicolumn{1}{c}{ Sig. } & Statistic & df & \multicolumn{1}{c}{ Sig. } \\
\hline Pre_Kom_7A &, 273 & 28 &, 000 &, 775 & 28 &, 000 \\
Pre_Kom_7B &, 526 & 28 &, 000 &, 361 & 28 &, 000 \\
Post_Kom_7A &, 346 & 28 &, 000 &, 755 & 28 &, 000 \\
PostKom 7B & .393 & 28 & .000 & .644 & 28 & .000
\end{tabular}

Berdasarkan tabel 6 , nilai signifikan Shapiro-Wilk berada di bawah $1 \%$ atau 0,01 . Hal ini mengindikasikan bahwa data kemampuan komunikasi matematis siswa, sebelum dan sesudah perlakuan baik kelas eksperimen maupun kontrol tidak berdistribusi normal, sehingga analisis dilakukan secara nonparametrik yaitu Uji Mann Whitney. Adapun hasilnya dapat dilihat pada tabel 7.

Tabel 7 Uji Mann Whitney

\begin{tabular}{lr}
\hline & Komunikasi \\
\hline Mann-Whitney U & 241,500 \\
Wilcoxon W & 647,500 \\
Z & $-2,728$ \\
Asymp.Sig (2-tailed) &, 006 \\
\hline \multicolumn{2}{c}{ Nilai signifikansi yang diperoleh } \\
adalah 0,006 dimana nilai tersebut berada di \\
bawah taraf signifikan 5\%. Hal ini \\
mengindikasikan bahwa terdapat pengaruh \\
pembelajaran berbasis kearifan lokal
\end{tabular}

yang dimiliki untuk memecahkan suatu permasalahan melalui masalah yang mereka buat. Hal ini sesuai dengan penelitian terkait problem posing terhadap kemampuan berpikir kritis dan komunikasi matematis siswa (Mahmuzah dkk, 2014; Sofyan \& Sukandar, 2015; Septiani, Sukestiyarno, \& Suyitno, 2013). Di samping itu, kemampuan berpikir kritis dan komunikasi matematis siswa di SMPN 1 Banjarbaru tergolong baik. Hal ini disebabkan karena SMPN 1 Banjarbaru merupakan sekolah yang siswanya menjadi perwakilan dalam bidang olimpiade matematika yang mewakili Kalimantan Selatan di Tingkat Nasional. Hal ini juga merupakan impilikasi dari kurikulum 2013 yang diterapkan di sekolah tersebut.

Melihat kondisi awal yang ditemukan pada penelitian ini dimana siswa sudah memiliki dasar dalam kemampuan berpikir kritis dan komunikasi matematis siswa, menjadikan hal tersebut sebagai fondasi 
agar kemampuan siswa terus dikembangan secara berkelanjutan. Pada dasarnya kemampuan interpretasi siswa dalam berpikir kritis dan konsolidasi dalam komunikasi matematis siswa tergolong baik. Hal ini juga menunjukkan bahwa siswa dapat memahami dan mengekspresikan arti dari berbagai suatu pengalaman, situasi, data, peristiwa, serta dapat mengkomunikasikannya secara tertulis berdasarkan informasi yang diberikan). Kemampuan inferensi siswa juga perlu disoroti, terkait dengan kemampuan siswa dalam mengidentifikasi dan mengamankan elemen yang diperlukan untuk menarik kesimpulan yang masuk akal (Facione, 2013)

Kemampuan berpikir kritis dan komunikasi matematis siswa merupakan kemampuan berpikir tingkat tinggi yang harus selalu dikembangkan oleh siswa. Problem posing merupakan salah satu pembelajaran yang dapat menstimulus kemampuan berpikir tingkat tinggi dan komunikasi matematis.

Di samping itu, pembelajaran problem posing berbasis kearifan lokal Kalimantan Selatan yang mengenalkan budaya lokal juga akan membentuk karakter siswa yang lebih mencintai dan memiliki rasa bangga terhadap budaya-budaya Indonesia.

\section{Saran}

Saran dalam penelitian ini adalah (1) perlu adanya pembelajaran yang berkelanjutan untuk mengembangkan kemampuan berpikir kritis dan komunikasi matematis siswa di sekolah tersebut; (2) perlu adanya penelitian lanjutan berkaitan dengan proses berpikir dan pengembangan buku ajar berbasis kearifan lokal Kalimantan Selatan.

\section{Ucapan Terima Kasih}

Terima kasih yang sebesar-besarnya kepada DRPM Kemenristekdikti yang telah membiayai penelitian ini.

\section{Daftar Pustaka}

Brown, \& Walter. (2013). Problem posing: reflection and application. New Jersey: Lawrence Erlabaum Associates.

Creswell, J. (2012). Educational Research: Planning, conducting, and evaluating quantitative and qualitative research. Boston: Pearson.

Facione, P. A. (2013). Critical Thinking: What It Is and Why It Counts. Insight Assesment.

\section{Simpulan dan Saran}

\section{Simpulan}

Simpulan dalam penelitian ini adalah (1) terdapat pengaruh pembelajaran problem posing berbasis kearifan lokal Kalimantan Selatan terhadap kemampuan berpikir kritis siswa; (2) terdapat pengaruh pembelajaran problem posing berbasis kearifan lokal Kalimantan Selatan terhadap kemampuan komunikasi matematis siswa.
Herawati dkk. (2010). Pengaruh Pembelajaran Problem Posing Terhadap Kemampuan Pemahaman Konsep Matematika Siswa Kelas XI IPA SMA Negeri 6 Palembang. Jurnal Pendidikan Matematika , 4 (1), 71-80.

Kemendikbud. (2012). Dokumen Kurikulum 2013. Jakarta: Kemendikbud.

Mahmudi, A. (2011). Problem Posing untuk Menilai Hasil Belajar Matematika. Seminar Nasional Matematika dan Pendidikan Matematika (hal. 20-29). 
Yogyakarta: Universitas Negeri Yogyakarta.

Mahmuzah dkk. (2014). Peningkatan Kemampuan Berpikir Kritis dan Disposisi Matematis Siswa SMP dengan Menggunakan Pendekatan Problem Posing. Jurnal Didaktik Matematika , 1 (2), 43-53.

Mishra, \& Iyer. (2015). An Exploration of Problem Posing Based Activities as An Assessment Tool and as an Instructional Strategy. Research and Practice in Technology Enhanced Learning , 10 (5), 1-19.

NCTM. (2000). Executive Summary: Principle and Standards for School Mathematics. Reston VA: NCTM.

OECD. (2016). PISA 2015:Result in Focus. OECD.

Permendikbud Nomor 160 Tahun 2014. (2014). Peraturan Menteri Pendidikan dan Kebudayaan Nomor 160 Tahun 2014. Jakarta: Kemendikbud.

Ragartz dkk. (2010). In the Mathematics Classroom in Indonesia: "TIMSS Video Study of Teaching and Learning Student Achievement. Jakarta: The World Bank.

Septiani, M., Sukestiyarno, \& Suyitno, A. (2013). Pembentukan Karakter dan Komunikasi Matematika Melalui Model Problem Posing Berbantuan Problem Posing Berbantuan Scaffolding Materi Segitiga. Jurnal Kreano , 4 (1), 41-49.

Sofyan, D., \& Sukandar, S. M. (2015). Meningkatkan Kemampuan Pemecahan Masalah dan Komunikasi Matematik Melalui Pendekatan Problem Posing. Jurnal Pendidikan Matematika , 6 (1), 16. Pengembangan Pendidikan Budaya dan Karakter Bangsa Melalui Pembelajaran Matematika di SD. Yogyakarta: Kemendiknas. 